\title{
Primary omental torsion in children: ten-year experience
}

\author{
George Mavridis · Evangelia Livaditi · \\ Nikolaos Baltogiannis · Evi Vasiliadou • \\ George Christopoulos-Geroulanos
}

Published online: 1 August 2007

(C) Springer-Verlag 2007

\section{Erratum to: Pediatr Surg Int}

DOI 10.1007/s00383-007-1961-3

The given name and family name of each of the first four authors were transposed. In addition, the given names of the first and fifth authors were incorrect. The correct names are as shown here.

The online version of the article can be found under doi:10.1007/s00383-007-1961-3.

G. Mavridis ( $\square$ )

2nd Surgical Department,

"Aghia Sophia"' Children's Hospital of Athens,

79 Alevizatou Str, 15669 Papagou, Athens, Greece

e-mail: mavridisg@hotmail.com

E. Livaditi - N. Baltogiannis - E. Vasiliadou

G. Christopoulos-Geroulanos

2nd Surgical Department,

"Aghia Sophia" Children's Hospital of Athens,

Thivon Str, 11527 Goudi, Athens, Greece 